\title{
INFLUENCE OF GRASSLAND RENOVATION METHODS ON DRY MATTER AND PROTEIN YIELDS AND NUTRITIVE VALUE
}

\author{
GAWEL, E. $.^{*}-$ GRZELAK, M. $^{2}$ \\ ${ }^{1}$ Institute of Soil Science and Plant Cultivation-State Research Institute \\ Czartoryskich 8, 24-100 Puławy, Poland \\ (phone: + 48-81-4786-794, + 48-81-4786-900, http://orcid.org/0000-0001-9050-4509) \\ ${ }^{2}$ Poznań University of Life Science, Department of Grassland and Natural Landscape \\ Dojazd 11, 60-656 Poznań, Poland \\ (phone: + 48 61-848-7423, + 48 61-848-7612, http://orcid.org/0000-0002-7579-6117) \\ *Corresponding author \\ e-mail:eliza.gawel@iung.pulawy.pl \\ (Received $8^{\text {th }}$ Oct 2019; accepted $21^{\text {st }}$ Jan 2020)
}

\begin{abstract}
The aim of the research conducted in 2013-2016 at Grabów, Mazowieckie Province, Poland was to compare the yield and nutritive value of a fodder after the renovation of sward and to assess the usefulness of certain legume-grass mixtures for undersowing. A two-factor experiment was established in which the first factor included 3 methods of renovating grassland: 1 - after ploughing; 2 - after the compact disc harrow; 3 - after destroying the old sward with herbicide, sowing with the slit seed drill for direct sowing (Moore type). The second factor was 3 legume-grass mixtures: Krasula, Cent 4 and original. Similar fodder dry matter yields and nutritive values. Along with the increasing percentage of legumes in the sward (under conditions of rainfall deficiency), the protein value of feed (PDI), protein yield and feed filling value (LFU) increased in subsequent years of use. A tendency to lower yields after sowing grassland sward with a mixture Cent 4, containing short-lived grass species (Lolium perenne L. and Lolium multiflorum Lam.), was observed. The mean nutritive value was suitable for use for meat cattle, dried dairy cows, while in the first year after undersowing, for good beef cattle, older heifers, marginally for dairy cows.
\end{abstract}

Keywords: compact harrow, direct sowing, legume-grasses mixtures, ploughing, relative nutritional value

Abbreviations: RSD, residual standard deviation; v\%, coefficient of variation; NDF, neutral detergent fibre $\left(\mathrm{g} \cdot \mathrm{kg}^{-1}\right)$; ADF, acid detergent fibre $\left(\mathrm{g} \cdot \mathrm{kg}^{-1}\right)$; ADL, acid detergent lignin's $\left(\mathrm{g} \cdot \mathrm{kg}^{-1}\right)$; UFL, feed unit for lactation; PDI, protein digested in small intestine $\left(\mathrm{g}^{\cdot \mathrm{kg}^{-1}}\right)$; LFU, value of the filling units for lactation; RFV, relative nutritional value

\section{Introduction}

Grassland is a source of low-cost and valuable roughage for grasslands animals, mainly ruminants. The high percentage of green forage and fodder processed from grasslands increases the profitability of milk and beef production, ensuring a stable income for farmers (Donnellan et al., 2012). Proper grassland management, productivity, and species and chemical composition play an important role in animal nutrition.

Worldwide, grassland produces food for about one billion people (De Vliegher et al., 2014). In Europe, they occupy about a third of the agricultural area (Lesschen et al., 2014) and are important not only for the production of animal feed and human food, but also for environmental functions which are now more important than economic functions. Grasslands have a positive impact on the natural environment, preventing soil erosion and carbon and nitrogen losses, constituting water reservoirs, maintaining the biodiversity of flora and fauna, increasing soil biological activity, limiting the effects of climate change (by collecting water), protecting nature, as well as providing biomass for energy purposes 
(Velthof et al., 2010; Zając et al., 2010; De Vliegher et al., 2014; Lesschen et al., 2014; Reinsch et al., 2018). In the recent 30 years, the grassland area has decreased, among other things, due to a decrease in the cattle population, deterioration in the quality of feed, and the introduction of protein concentrates and low-cost soya beans in animal feed, as well as the abandonment of certain grassland (De Vliegher et al., 2014).

In Europe there is a large regional variation in grassland productivity, where the highest productivity, of about $10 \mathrm{t} \cdot \mathrm{ha}^{-1}$, is observed in the regions of north-western Spain, the Netherlands, western France, northern Germany, Ireland (Lesschen et al., 2014). In Poland, according to the Central Statistical Office (GUS) data, in 2017 the yields obtained on permanent meadows amounted to $5.42 \mathrm{t} \cdot \mathrm{ha}^{-1}$, while on pastures they were even lower (GUS, 2018).

Decrease in yield levels, weed infestation of sward, and its simplified species composition, as well as errors in pratotechniques (i.e., improper use, inadequate fertilization, or one-sided fertilization with nitrogen only), appearance of grass species of low economic value in sward, lack of legumes, inadequate climatic conditions, and in particular, the shortage of precipitation, all lead to the degradation, as a result of which grasslands have to be renovated (Kulik, 2010; Terlikowski and Barszczewski, 2015). This can be carried out by different methods including: fertilization and rational use; reseeding of low-cut sward in a traditional way or with machines constructed for this purpose after mechanical, or chemical destruction of a part of the sward with a heavy harrow or a tiller and applying the method of full tillage after ploughing to completely destruct the old sward (Mocanu and Hermenean, 2009; Kulik, 2010; Zając et al., 2010; Elsaesser, 2012; Reheul et al., 2017). Renovation by full tillage after ploughing, consisting of ploughing up, inverting the furrow-slice and carrying out a set of pre-sowing tillage, is considered the most radical, unfavourable for the environment and costly type of renovation, because it destroys the soil structure. The aerated soil organic matter releases nitrogen and phosphorus and washes out in the form of soluble forms of these components (Kulik, 2010; Velthof et al., 2010; Zając et al., 2010; De Vliegher et al., 2014). McDonald et al. $(2011 \mathrm{a}, \mathrm{b})$ showed higher mineralization and loss of $\mathrm{N}_{2} \mathrm{O}$ and higher leaching of soluble carbon by $10-30 \%$ both in manure fertilization and manure-free fertilization after the application of herbicide for the renovation of grassland than after the ploughing and a full set of pre-sowing procedures. Grasslands retain more greenhouse gases than arable land, so their ploughing and conversion to arable land has more drastic environmental consequences. Fewer side effects accompany the renovation of grassland with less invasive methods such as: direct sowing, tillage using rotary tillers and undersowing (Mocanu and Hermemean, 2009; Kulik, 2010; Łyszczarz et al., 2010; Velthof et al., 2010; Zając et al., 2010; Golka et al., 2016). The rate of organic matter mineralization on permanent grassland. On mineral soil can be reduced by ploughing in autumn, and on organic soil - in spring. Studies by Reheul et al. (2017) and Reinsch et al. (2018) did not confirm the effect of the ploughing date (autumn, spring) on yields and $\mathrm{N}_{2} \mathrm{O}$ emissions, as similar yields were obtained after ploughing in autumn and spring. According to these authors, $\mathrm{N}_{2} \mathrm{O}$ emissions are affected by quality of fodder after grassland renovation (Rehel et al., 2017; Reinsch et al., 2018).

In literature, there are different opinions regarding the increase in the level of yield and the improvement of the feed quality after the renovation of greenery. Mocanu and Hermenean (2009), who renovated the sward by direct sowing with a special seed drill, achieved an increase in dry matter yield by $48.5 \%$ to $134 \%$ in of protein yield by $105-129 \%$ in relation to the control (degraded meadow). Kayser et al. (2018) believe that 
all renovation techniques lead to an increased productivity and that the renewed sward should be used properly to maintain valuable grass and legume species. Łyszczarz et al. (2010), in turn, describe the re-degradation of sward already after about three years after renovation, when the yield of the renovated sward became equal to that obtained on meadows not fertilized for 20 years. The effects of the renovation are not always positive, as there is often no increase in yield and quality of the forage and no guarantee of a longterm renovation effect (Elsaesser, 2012).

It was decided to evaluate the effect of grassland renovation methods on the yield of dry matter and protein as well as the relative nutritional value of fodder in conventional conditions. The usefulness for reseeding of several legume-grass mixtures available on the Polish market was also checked.

\section{Material and methods}

\section{Site, location, and climate}

A two-factor field experiment was carried out at the Agricultural Experimental Station of the Institute of Soil Science and Plant Cultivation in Grabów, Mazowieckie Voivodeship ( $51^{\circ} 21^{\prime} \mathrm{N} ; 21^{\circ} 40^{\prime} \mathrm{E}$ ), Poland in the years of 2013-2016. It was established on according to FAO - WRB classification system 2014, Umbrisols and Phaeozems. It was characterized by a neutral reaction $(\mathrm{pH}$ in $1 \mathrm{M} \mathrm{KCl} \mathrm{6.6)} \mathrm{the} \mathrm{available} \mathrm{nutrient} \mathrm{content}$ of the soil was as follows ( $\mathrm{mg} \cdot 100 \mathrm{~g}^{-1}$ soil): phosphorus 10.8 (average content), potassium 6.02 (low content) and magnesium 12.3 (high content).

\section{Meteorological conditions}

The field experiment was located in a temperate continental climate zone. Meteorological conditions during the study period were varied (Fig. 1). In Polish condition, for permanent meadows, optimal rainfall during the growing season is $420 \mathrm{~mm}$, slightly larger are characterized by permanent pastures $-450 \mathrm{~mm}$, rainfall distribution in individual months is also important (Grabarczyk, 1989). According to this author (Grabarczyk, 1989), optimal rainfall in meadows and pastures grasslands and average air temperature should be: in April - precipitation - $50 \mathrm{~mm}$, average air temperature $-8^{\circ} \mathrm{C}$; in May - rainfall of $65 \mathrm{~mm}$ (meadows) and $70 \mathrm{~mm}$ (pastures), air temperature $-13^{\circ} \mathrm{C}$; in June - rainfall $-80 \mathrm{~mm}$ (meadows) and $90 \mathrm{~mm}$ (pastures), air temperature $-16^{\circ} \mathrm{C}$; in July - rainfall $90 \mathrm{~mm}$ (meadows) and $100 \mathrm{~mm}$, air temperature $18^{\circ} \mathrm{C}$; in August - precipitation is $80 \mathrm{~mm}$ of precipitation, air temperature $-17^{\circ} \mathrm{C}$; in September - rainfall $55 \mathrm{~mm}$ (meadows) and $60 \mathrm{~mm}$ (pastures), air temperature $14^{\circ} \mathrm{C}$. Optimal rainfall for grassland was recorded in May 2014 (120 mm precipitation), June 2013 (115 mm precipitation), July and August 2014 (100 mm and $80 \mathrm{~mm}$, respectively) and in September 2015 (93,9 $\mathrm{mm})$. In the remaining research period, and especially in 2016, the lack of rainfall was significant, therefore in the second and third years of use (2015 and 2016) the efficiency of thinned sward was estimated only in the first three shoots. The last revival of sward was grazed without prior crop evaluation or botanical mass analysis.

The mixtures were sown under good humidity and thermal conditions, after heavy but uneven rainfall. Favourable conditions promoted the germination, initial growth and development of crops and weeds. In summer, weather conditions deteriorated during the sowing year. In 2014, the average monthly precipitation was above the long-term average 
for this period, with the highest storm precipitation in May (Fig. 1). In 2015, May, June and September, humidity conditions were conducive to the development of the sward. In the remaining period, the deficiency of precipitation and temperatures higher than the long-term average, resulted in poor regrowth, therefore only three sward harvests were carried out. The year of 2016 was the driest and warmest year compared to the other years, so the growth of the sward in this period was limited. As in the previous year, only 3 harvests were carried out, and the fourth sward regrowth was grazed upon by cows. Habitat and climate conditions determine the success of the renovation. Of special importance are humidity conditions in the year of sowing, not only during the procedure but also within a few days after sowing (Bélanger and Tremblay, 2010).

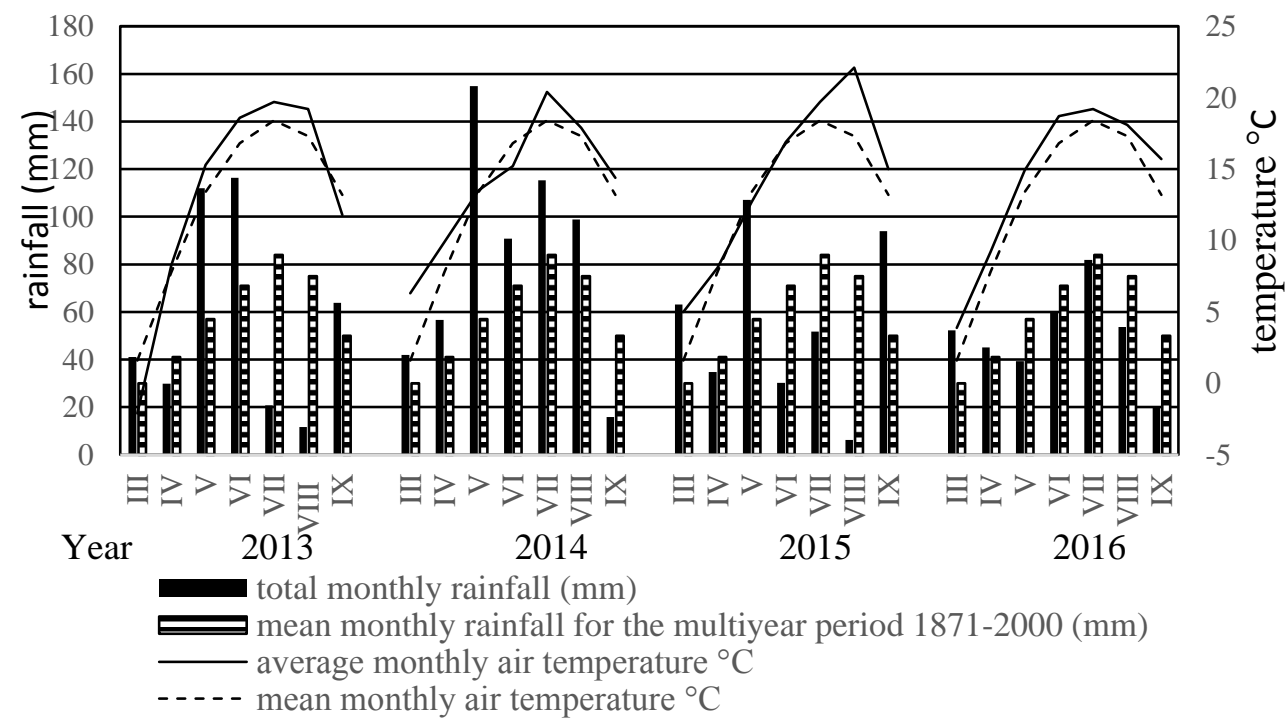

Figure 1. Meteorological condition in the years 2013-2016 Grabów, Poland during the growing season

\section{Experimental treatments and design}

Studies on the effect of grassland renovation on dry matter, protein yield, and nutritive value of the renovated sward were carried out in a two-factor experiment sown in the split-block system, in four replicates, on a gross area of 0.6 ha. The factors studied were three methods of renovating grassland:

1) ploughing and full tillage, plus sowing of legume-grass mixtures with a grain seed drill;

2) destruction of the sward with a compact disc harrow and sowing of seeds with a grain seed drill;

3) destruction of the old sward with a herbicide and sowing of seeds with a seed drill (Moore type). The second factor were three mixtures of legumes and grasses:

$\mathrm{K}$ - Krasula $+3.5 \mathrm{~kg}$ white clover (Trifolium repens L.) 'Romena' consisting of: perennial ryegrass (Lolium perenne L.) (25.7\%), Italian ryegrass (Lolium multiflorum Lam.) $(9.19 \%)$, meadow timothy (Phleum pratense L.) (13.79\%), orchard grass (Dactilis glomerata L.) (9.19\%), red fescue (Festuca rubra L.) (9.19\%), tall fescue (Festuca arundinacea Schreb.) (9.19\%), sheep's fescue (Festuca ovina L.) (4.59\%), red clover (Trifolium pratense L.) (4.59\%), lucerne (Medicago sativa L.) (4.59\%), bent grass 
(Agrostis alba L.) $(1.83 \%)+3.5 \mathrm{~kg} \cdot \mathrm{ha}^{-1}$ white clover (Trifolium repens L.) ('Romena', $8.11 \%)$; seed sowing rate $-40 \mathrm{~kg} \cdot \mathrm{ha}^{-1}$.

C - Cent 4 consisting of: perennial ryegrass (Lolium perenne L.) (40.0\%), Italian ryegrass (Lolium multiflorum Lam.) (10.0\%), tall fescue (Festuca arundinacea Schreb.) (15.0\%), meadow fescue (Festuca pratensis Huds.) (5.0\%), meadow timothy (Phleum pratense L.) (5.0\%), meadow bluegrass (Poa pratensis L.) (5.0\%), festulolium (Festulolium braunii (K. Richt.) A. Camus) (5.0\%), lucerne (Medicago sativa L.) (10.0\%) and white clover (Trifolium repens L.) $(5.0 \% \%)$; see sowing rate $-35 \mathrm{~kg} \cdot \mathrm{ha}^{-1}$.

$\mathrm{O}$ - original mixtures consisting of: of white clover (Trifolium repens L.) 'Barda' (10.0\%), hybrid lucerne (Medicago x varia Martyn Fl. Rust.) 'Radius' (20.0\%), red clover (Trifolium pratense L.) 'Milena' (20.0\%) (legumes accounting for $50.0 \%$ in total), perennial ryegrass (Lolium perenne L.) 'Artemis' (15.0\%), orchard grass (Dactilis glomerata L.) 'Amila' (15.0\%), meadow fescue (Festuca pratensis Huds.) 'Anturka' (10.0\%), festulolium (Festulolium braunii (K. Richt.) A Camus) 'Agula' 10.0\% in pure sowing; seed sowing rate $-23 \mathrm{~kg} \cdot \mathrm{ha}^{-1}$.

In the spring of 2013, the necessary cultivation procedures were carried out on the grassland to be renovated in accordance with the experiment scheme. The ploughing was carried out to a depth of $30 \mathrm{~cm}$ (treatment 1). Under the conditions of the renovation, the top layer of soil was loosened to the depth of $5 \mathrm{~cm}$ with a compact disc harrow (treatment 2) by a simplified method. On the treatments with direct sowing, the development of degraded sward was inhibited with Roundup 360 SL at a dose of 61 per hectare (treatment 3 ). Legume-grass mixtures were sown in the second decade of June. In the summer, the sward was mowed twice in order to inhibit the development of weeds. In October the whole area of the experiment was grazed upon by cows. A total of 6 cuts of sward for haylage were carried out during the study and 9 short term grazing's (2-3 days of grazing) of 79-85 productive cows, were carried out. In the sowing year, two swaths were made for the mechanical weeding of sward mixtures and one grazing of cows on the surface of the entire experiment (2013 year). In the first year of use (2014 year), the first and second regrowth of sward was cutting, while in the second and third year of use (2015 and 2016 year) only first sward regrowth was intended for silage. Cows were grazed on the remaining sward regrowth. During the period of field research in the years 2023-2016 no chemical protection of sward mixtures was carried out.

\section{Pre-sowing and top dressing fertilization}

Superphosphate $\left(40 \% \mathrm{P}_{2} \mathrm{O}_{5}\right)$ in the amount of $60 \mathrm{~kg} \mathrm{ha}^{-1} \mathrm{P}_{2} \mathrm{O}_{5}$ and potassium salt $(60 \%$ $\mathrm{K}_{2} \mathrm{O}$ ) in the dose of $60 \mathrm{~kg} \mathrm{ha}^{-1}$ were used before the sowing.

In each year of full use, during the spring start of the mixture's growing season, it was fertilized with phosphorus $-80 \mathrm{~kg} \mathrm{ha}^{-1} \mathrm{P}_{2} \mathrm{O}_{5}$, potassium $-36 \mathrm{~kg} \mathrm{ha}^{-1} \mathrm{P}_{2} \mathrm{O}_{5}$ and nitrogen (ammonium nitrate) $-34 \mathrm{~kg} \mathrm{ha}^{-1} \mathrm{~N}$. After the first regrowth was harvested, the sward was fertilized with potassium - $60 \mathrm{~kg} \mathrm{ha}^{-1} \mathrm{~K}_{2} \mathrm{O}$ in the first year of use, $40 \mathrm{~kg} \mathrm{ha}^{-1} \mathrm{~K}_{2} \mathrm{O}$ in the following years, and with nitrogen $31 \mathrm{~kg} \mathrm{ha}^{-1} \mathrm{~N}$. In the second year of use, phosphorus in the dose of $40 \mathrm{~kg} \mathrm{ha}^{-1} \mathrm{P}_{2} \mathrm{O}_{5}$ was also applied. In all years of use, after the second and third harvest / grazing, the sward was fertilised with nitrogen in the amount of $31 \mathrm{~kg} \mathrm{ha}^{-1} \mathrm{~N}$.

\section{Measurements}

Green matter yield was determined on the basis of green forage samples taken from the area of $10 \mathrm{~m}^{2}$ from each plot. During harvesting, two samples of green forage weighing $0.5 \mathrm{~kg}$ were taken to calculate the drying rate (\%) and to perform a simplified 
botanical analysis of sward (grass of all species together, lucerne, white and red clover together, weeds). An analysis of the botanical composition of sward was carried out in each regrowth, and the percentage of a given plant fraction (lucerne; clover; grasses) in the total dry matter of the sample, was calculated.

\section{Chemical analysis}

The assessment of the chemical composition and feed value of the sward was carried out in an accredited IUNG-PIB laboratory in Puławy, Poland. Plant material from the first sward regrowth, in each of the 3 years of full use, was analysed. For chemical analyses, a sample of $0.5 \mathrm{~kg}$ of green fodder was taken from each plot. After drying, the plant material was combined into object tests and ground. Chemical analysis was carried out in some of the prepared plant material. The dry matter content of mixtures was determined by weight method according to test procedure PB 35.1 - first edition -10.05. 2013, total nitrogen - flow analysis (CFA) (PB 33.1- second edition -05.03.2014); while the contents of crude fibre and fibre fraction (Neutral Detergent Fibre -NDF; Acid Detergent Fibre ADF; Acid Detergent Lignin's - ADL) - according to test procedure PB 51. 1 - second edition - 01.08.2013. The results of chemical analyses were used for the nutritional assessment of biomass according to the Linn and Martin (1989) based on the fibre fraction content. The evaluated classification parameter was relative feed value calculated on the basis of fibre fraction content according to the formula (Eq. 1) (Linn and Martin, 1989):

$$
\mathrm{RFV}=[\mathrm{DDM} \times \mathrm{DMI}]: 1.29
$$

where,

DDM (dry matter digestibility in \%) $=88.9-0.779 \times$ ADF, DMI (dry matter intake in \% body weight $)=(\mathrm{DMI}=120: \mathrm{NDF})$, $\mathrm{NDF}$ - neutral detergent fibre, ADF - acid detergent fibre.

The relative feed value (RFV) obtained from the calculation was compared with feed quality classes and the ranges of RFV developed by Jeranyama and Garcia (2004) for cattle.

\section{Statistical analysis}

For comparison of dry matter yields and total protein yields in the first cut, the content of total protein, crude fibre in mixtures' dry matter, digestibility of organic mass, content of neutral and acid detergent fibre (NDF, ADF and ADL), as well as relative nutritional value, the analysis of variance was applied. Calculations were performed in the program Statistica (Stat Soft Inc., USA). The Tukey's test $(\mathrm{P} \leq 0.05)$ compared the mean values for the factors tested in the field experiment; the $1^{\text {st }}$ factor - three methods of grassland renovation; the $2^{\text {nd }}$ factor - three legume-grass mixtures.

\section{Results and discussion}

\section{Botanical composition}

In the sward renovated with the full tillage method after ploughing (1), after disc harrow (2) and after the application of herbicide and direct sowing (3), in all years of use, grasses dominated in spring regrowth (Fig. 2). Their percentage was varied and amounted 
to about $72 \%$ to $93 \%$ of the sward. The percentage of legumes in the sward increased in summer and autumn, and in the second and third year of use, there were more legumes than grasses in the sward. Among legumes, in the first two years of use of mixtures, there were more clovers (white clover and red clover in total) than lucerne in the sward. However, the situation changed due to a shortage of precipitation. In the third year of use, lucerne prevailed in the sward, as this plant tolerated the deepening drought, while part of clover and grass plants receded from the sward during this period.

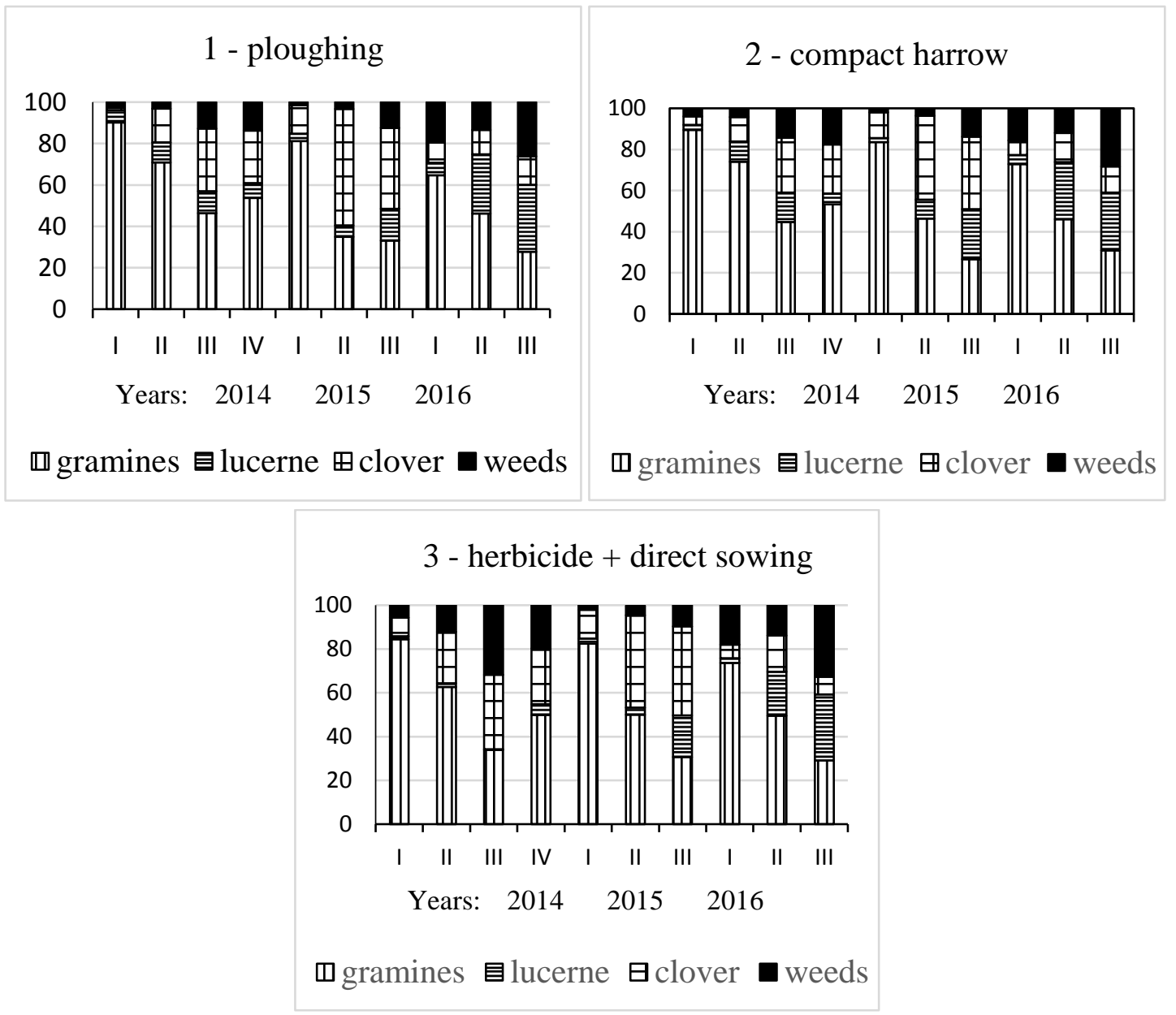

Figure 2. Percentage of components in the dry matter yield of legume-grass mixtures depending on the method of sward renovation in 2014-2016 (\%)

Due to different sensitivity to drought, multi-species mixtures of legumes and grasses should be used for the renovation of grasslands as their varied development in subsequent years of use and different water needs may increase the sward longevity and success of this procedure (Lyszczarz et al., 2010; Isselstein and Kayser, 2015). Under non-precipitation conditions, weed infestation of the sward increased, especially in the second and third year of use (Fig. 2), being particularly high at the end of the third year of use. The sward weeded faster on the treatment with the use of herbicide to inhibit the development of sward and with direct sowing with a special slit seed drill (treatment 3 ). In this research treatment, part of the weeds was not completely destroyed by herbicide spraying and regenerated quite quickly. The same was true for the simplified tillage, 
which involved moving the topsoil to a depth of $5 \mathrm{~cm}$ with a compact disc harrow (treatment 2), where some legumes and weeds with a deep root system (such as Taraxacum officinale Wep.) grew back quickly.

There were $18 \%$ of legumes (including red clover, lucerne and white clover) in the sown mixture Krasula seeds, $15 \%$ - in the mixture Cent 4 (lucerne, white clover), and $50 \%$ in the original mixture (white clover, hybrid clover and red clover). The percentage of components in the sward of mixtures changed dynamically in the years of use, and varied significantly from the species composition of seed mixtures (Fig. 3). In the spring of the first year of use, grasses dominated in the sward of the compared mixtures (from about $80 \%$ to $92 \%$ of the sward yield). However, already in the third growth of sward, their percentage was only about $40 \%$ of dry matter yield. In this period the percentage of clovers and weeds increased as well. In every year of use, in summer and autumn, when the lack of moisture in the soil was significant, legumes dominated in sward (especially in 2015 and 2016). In the second year (2015), these were clovers, while in the drier third year of use (2016) - lucerne. The weed infestation of the sward increased as well, with the highest weed infestation during the whole period of use being recorded for mixture Cent 4. At the end of the third year of use, weeds accounted for as much as $47 \%$ of the dry matter yield of this mixture. At that time, the sward of the original mixture was the least weeded (about $17 \%$ of weeds).

A small number of herbs and weeds in the sward (especially when used for grazing) is attractive for animals, as it improves the taste of the sward, and in the case of legumes, also the quality of feed, because the rate of decrease in the nutritive value of this group of plants is lower than that of grasses (Peyraude et al., 2009). Factors that make it possible to maintain biodiversity in the sward include proper use, proper fertilization, and grazing upon by a small number of animals, as well as proper selection of legume and grass species for mixtures (Klimek et al., 2007; De Vliegher et al., 2014; Głąb et al., 2016).

\section{Dry matter production}

During the three-year period of use, the method of renovation (full tillage after ploughing - treatment 1; surface soil disturbance to a depth of $5 \mathrm{~cm}$ with a compact disc harrow - treatment 2; sward spraying with herbicide and direct sowing - treatment 3) had no significant effect on dry matter yields (Table 1). In the years of use, no interaction was found between the factors investigated, i.e. the method of renovation of green use and mixtures used for renovation. The coefficient of variation $(\mathrm{v} \%)$ indicates a small differentiation of dry matter yields in the first and second year of use of mixtures (2014 and 2015 years) and average yield changes in the third year of use of mixtures (2016 years; $\mathrm{v} \%=24.9$ ).

The highest yields were harvested in the first year of use (from 10.65 to $11.21 \mathrm{t} \mathrm{ha}^{-1)}$. In the following years, the yield decreased due to deteriorating humidity conditions and summer drought. The lowest yields (about $8.4 \mathrm{t} \mathrm{ha}^{-1}$ ) were obtained in the second year of full use (2015), when the deficit of precipitation in relation to the long-term average was the highest (Table 1). Good pluviometric conditions before sowing and in the year following the renovation were conducive to the development and yield of the mixtures. Similar observations on this subject are presented by Bélanger and Tremblay (2010). Literature contains various contradictory information about the yields of the renovated sward. Terlikowski and Barszczewski (2015) and Golka et al. (2016), after the renovation, achieved improved yield and use value of sward. However, Velthof et al. (2010), Reheul et al. (2017), Grace et al. (2018) and Kayser et al. (2018) argue that renovation does not 
always lead to higher sward yields. Kulik (2010) considered the resowing performed directly into the old sward (without earlier inhibition of sward development) to be the most unreliable method of renovation in comparison with the use of herbicide or a tiller to limit the growth of the degraded sward. In turn, in the studies of Łyszczarz et al. (2010), the use of herbicide and disc harrow before resowing turned out to be the most effective method of renovation, while direct sowing into the sward with special seeders was completely unsuccessful.
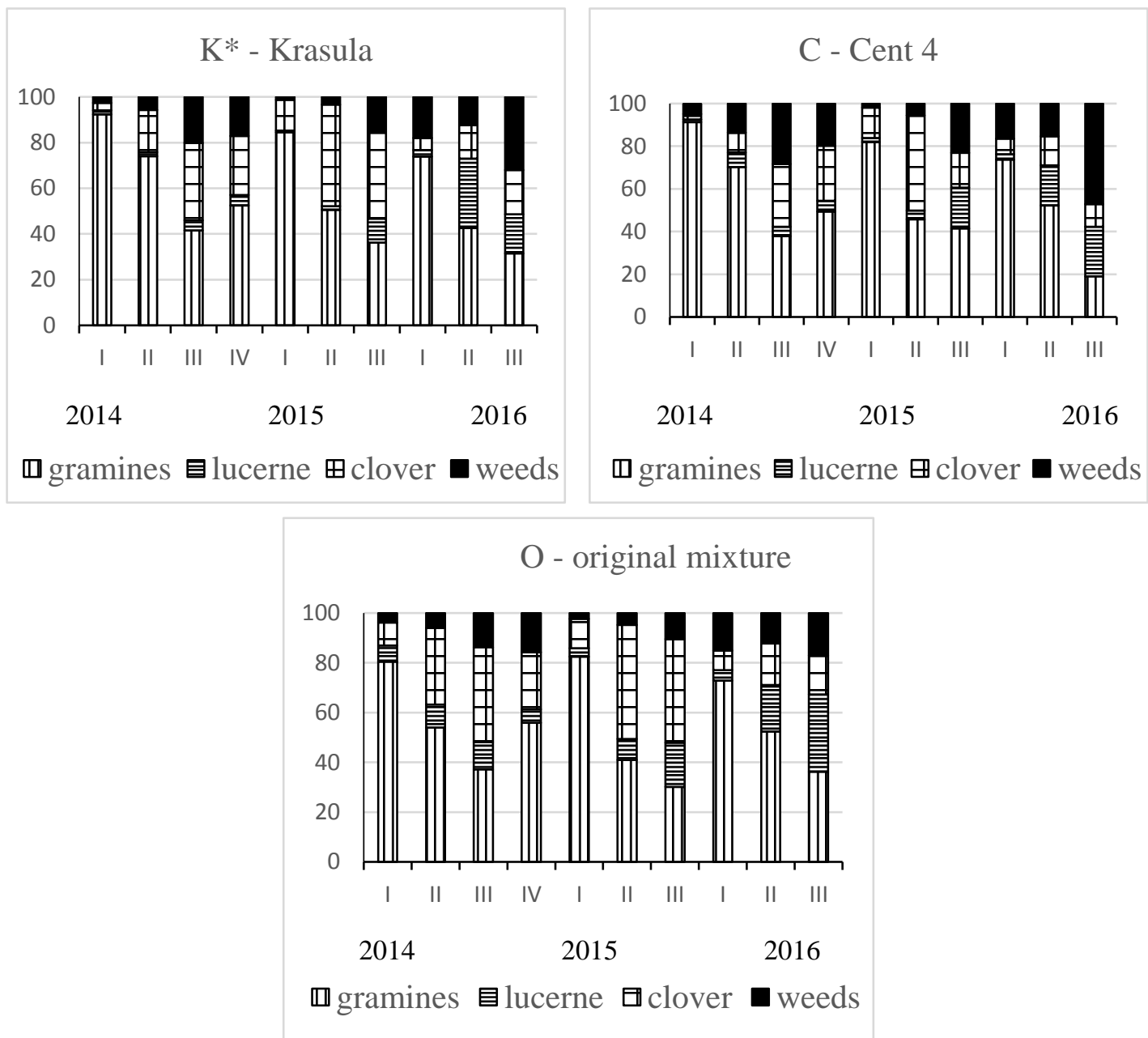

Figure 3. Influence of mixture species composition on the percentage of components in the dry matter yield (\%).

$K^{*}$ - Krasula: Lolium perenne L. (25.7\%), Lolium multiflorum Lam. (9.19\%), Phleum pratense L. (13.79\%), Dactilis glomerata L. (9.19\%), Festuca rubra L. (9.19\%), Festuca arundinacea Schreb. (9.19\%), Festuca ovina L. (4.59\%), Trifolium pratense L. (4.59\%), Medicago sativa L. (4.59\%), Agrostis alba L. (1.83\%) + $3.5 \mathrm{~kg}$ Trifolium repens L. 'Romena' (8.11\%)

C - Cent 4: Lolium perenne L. (40.0\%), Lolium multiflorum Lam. (10.0\%), Festuca arundinacea Schreb. (15.0\%), Festuca pratensis Huds. (5.0\%), Phleum pratense L. (5.0\%), Poa pratensis L. (5.0\%), Festulolium braunii (K. Richt.) A. Camus (5.0\%), Medicago sativa L. (10.0\%), Trifolium repens $L .(5.0 \% \%)$;

$O$ - original mixtures: Trifolium repens L. 'Barda' (10.0\%), Medicago x varia Martyn Fl. Rust. 'Radius' (20.0\%), Trifolium pratense L. 'Milena' (20.0\%), Lolium perenne L. 'Artemis' (15.0\%), Dactilis glomerata L. 'Amila' (15.0\%), Festuca pratensis Huds. 'Anturka' (10.0\%), Festulolium braunii (K. Richt.) A Camus 'Agula' $10.0 \%$ in pure sowing 
Table 1. Influence of the usage of the renovation of the grassland and species composition of legume-grass mixtures on the annual yield of dry matter

\begin{tabular}{|c|c|c|c|c|}
\hline \multirow{2}{*}{$\begin{array}{l}\text { Usage of the } \\
\text { renovation of the } \\
\text { grassland (A) }\end{array}$} & \multicolumn{4}{|c|}{ Mixtures (B) } \\
\hline & $\mathbf{K}^{* *}$ & $\mathbf{C}$ & $\mathbf{O}$ & Means \\
\hline \multicolumn{5}{|c|}{2014 years } \\
\hline $1^{*}$ & 11.56 & 10.09 & 11.98 & 11.21 \\
\hline 2 & 9.94 & 10.22 & 12.82 & 10.99 \\
\hline 3 & 11.36 & 9.40 & 11.20 & 10.65 \\
\hline Means & 10.95 & 9.90 & 11.99 & - \\
\hline \multicolumn{4}{|c|}{ LSD 0.05 for A- n.S.; B- 1.70; B/A - n.S.; A/B - n.S.; RSD = 2.78; v\% - 15.2} & - \\
\hline \multicolumn{5}{|c|}{2015 years } \\
\hline 1 & 9.35 & 8.17 & 7.81 & 8.44 \\
\hline 2 & 8.31 & 8.02 & 8.84 & 8.39 \\
\hline 3 & 8.57 & 7.56 & 10.14 & 8.75 \\
\hline Means & 8.74 & 7.91 & 8.93 & - \\
\hline \multicolumn{4}{|c|}{ LSD $_{0.05}$ for A- n.s.; B - n.s.; B/A - n.s.; A/B - n.s.; RSD - 1.73; v\% - 15.4} & - \\
\hline \multicolumn{5}{|c|}{2016 years } \\
\hline 1 & 10.32 & 9.39 & 9.10 & 9.60 \\
\hline 2 & 8.67 & 8.41 & 8.95 & 8.68 \\
\hline 3 & 7.05 & 7.00 & 8.36 & 7.47 \\
\hline Means & 8.68 & 8.26 & 8.80 & - \\
\hline \multicolumn{4}{|c|}{ LSD $_{0,05}$ for A-n.S.; B - n.S.; B/A - n.s.; A/B - n.s.; RSD - 4.58; v\% - 24.9} & - \\
\hline
\end{tabular}

Usage of the renovation of the grassland: $1^{*}$ - ploughing, 2 - compact disc harrow, 3 - herbicide + direct sowing. Mixtures: $\mathrm{K}^{* *}$ - see Figure 3, RSD - Residual Standard Deviation, v\% - coefficient of variation. Values in bold are statistically significant $(\mathrm{P} \leq 0.05)$

The species composition of legume-grass mixtures used for resowing the sward had a significant impact on the yields only in the first year of use (2014) (Table 1). Statistical analysis showed that the original mixture (treatment A) produced significantly higher yields (about $\left.12 \mathrm{t} \cdot \mathrm{ha}^{-1}\right)$ in comparison of with mixture Cent $4\left(9.90 \mathrm{t} \mathrm{ha}^{-1}\right)$. The original mixture (treatment A) consisted of 3 species of legumes: white clover (10\%), hybrid lucerne $(20 \%)$ and red clover $(20 \%)$, while the mixture Cent 4 was composed of two species of legumes in smaller amounts: lucerne (10\%) and white clover (5\%). Earlier studies confirmed the effect of the percentage and species of legumes on the yield and quality of feed obtained from legume-grass mixtures (Elgersma and Søegaard, 2016, 2018). In other studies, the lack of common cocksfoot in the mixture used for sowing and the high proportion of perennial and Italian ryegrass were found to be the cause of low yields of dry matter, energy, and protein per unit area (Gaweł et al., 2018). Legumes from the mixtures enter into symbiosis with nitrogen-binding bacteria from the air, which in different amounts, depending on the species or even the cultivar of legume, is transferred to the grasses in the mixtures. Therefore, the longevity and frost resistance of this group of plants affects the quality of feed from the mixtures (Bélanger and Tremblay, 2010). In addition, the grasses absorb nitrogen from the soil by absorbing the biologically-bound nitrogen. Isselstein and Kayser (2015) recommend multispecies legume-grass mixtures for renovation of sward, but their opinion is not always confirmed in practice, as evidenced by similar yields of multispecies and simplified mixtures described by Grace et al. (2018).

In the second and third year of use (2015 and 2016), when humidity conditions deteriorated, the dry matter yield of the compared mixtures did not differ significantly, amounting to 7.91-8.86 $\mathrm{t} \mathrm{ha}^{-1}$ (Table 1). In this period, the lowest yield was obtained from a mixture the Cent 4 , in which perennial ryegrass and Italian ryegrass accounted for $50 \%$, 
while the common cocksfoot did not occur at all. This type of grass, according to our own research, determines the durability and productivity of sward after resowing (Gawel, 2017; Gawel et al., 2018) (Table1).

\section{Organic components}

In the period of three years of use, no significant differences were found in the concentration of total protein, crude fibre and organic matter digestibility in the sward renewed with comparable methods: full tillage after ploughing (treatment 1) and simplified tillage after surface soil disturbance to the depth of $5 \mathrm{~cm}$ (treatment 2), as well as after the inhibition of sward development with herbicide and direct sowing (treatment 3) (Table 2). Different results were obtained under ecological conditions, where the sward renovated using the simplified method after the compact harrow (treatment 2) had a higher content of total protein than the sward after ploughing (treatment 1) (Gawel, 2017). There was no significant effect of the percentage and species of legumes in the sown mixtures on the abundance of the first cut in total protein. Vasiljević et al. (2011) describes seasonal changes and significant differences among cultivars of red clover in total protein concentration. In our own studies, the total protein content of sward increased in the third year of use, as legumes were better able to withstand the lack of moisture in the soil and their percentage in the sward was higher than that of grasses. In Mediterranean conditions, Mantino et al. (2016) also showed a positive correlation of the share of lucerne in the sward with the protein content in the dry matter of the mixtures and negative with the concentration of the neutral fibre fraction (NDF). Tremblay et al. (2015) believe that correctly selected species of legumes and grasses for mixtures offer an opportunity to balance energy and protein in feed.

Table 2. Content of organic components and digestibility of feed in the first cut $\left(\mathrm{g} \mathrm{kg}^{-1}\right)$

\begin{tabular}{|c|c|c|c|c|c|c|c|c|c|}
\hline \multirow{3}{*}{ Specification } & \multicolumn{3}{|c|}{$\begin{array}{c}\text { Total } \\
\text { protein }\end{array}$} & \multicolumn{3}{|c|}{$\begin{array}{c}\text { Crude } \\
\text { fibre }\end{array}$} & \multicolumn{3}{|c|}{$\begin{array}{c}\text { Digestibility of } \\
\text { organic mass }\end{array}$} \\
\hline & \multicolumn{9}{|c|}{ Year of utilization } \\
\hline & $\mathbf{1}^{\text {st }}$ & $2^{\text {nd }}$ & $3^{\text {rd }}$ & $\mathbf{1}^{\text {st }}$ & $2^{\text {nd }}$ & $3^{\text {rd }}$ & $1^{\text {st }}$ & $2^{\text {nd }}$ & $3^{\text {rd }}$ \\
\hline \multicolumn{10}{|c|}{ Usage of the renovation of the grassland } \\
\hline 1 - ploughing & 79.58 & 62.73 & 118.75 & 300.6 & 349.0 & 296.3 & 711.4 & 707.3 & 517.5 \\
\hline 2 - compact harrow & 104.37 & 80.63 & 102.08 & 277.0 & 318.7 & 311.0 & 710.9 & 709.1 & 536.5 \\
\hline $\begin{array}{l}3 \text { - herbicide + direct } \\
\text { sowing }\end{array}$ & 80.62 & 67.93 & 114.58 & 296.7 & 335.7 & 314.7 & 710.3 & 713.5 & 511.1 \\
\hline \multicolumn{10}{|c|}{ Mixtures } \\
\hline $\begin{array}{l}\text { K - Krasula + 3.5 kg } \\
\text { white clover }\end{array}$ & 71.87 & 73.80 & 108.33 & 301.0 & 331.7 & 331.0 & 713.5 & 711.2 & 530.5 \\
\hline C - Cent 4 & 91.05 & 58.33 & 118.75 & 284.7 & 346.0 & 276.7 & 711.2 & 709.9 & 516.5 \\
\hline O - Original mixture & 101.65 & 79.17 & 108.33 & 288.7 & 326.3 & 314.3 & 707.9 & 708.7 & 518.1 \\
\hline
\end{tabular}

Usage of the renovation of the grassland: $1^{*}$ - ploughing, 2 - compact disc harrow, 3 - herbicide + direct sowing. Mixtures: $\mathrm{K}^{* *}$ - see Figure 3 . Values in bold are statistically significant $(\mathrm{P} \leq 0.05)$

In the second year of use, in the conditions of the renovation with the simplified method, after surface soil disturbance to the depth of $5 \mathrm{~cm}$ (treatment 2), the abundance of dry matter in fibre was significantly lower in comparison to the one obtained on the treatment with the renovation after ploughing (treatment 1) (Table 2). The species composition of mixtures used for resowing had no effect on the crude fibre content, which 
ranged from 276.67 to $346.00 \mathrm{~g} \mathrm{~kg}^{-1}$ dry matter. The method of renovation and species composition of mixtures for resowing of the sward did not significantly affect the digestibility of organic matter. A significant decrease in organic matter digestibility in the third year of use was probably due to high weed infestation and the predominance of legumes in the sward of mixtures (Figs. 1 and 2). It is known from the literature that legume plants are characterized by a high concentration of crude fibre, especially of lignin fraction (Montino et al., 2016; Elgersma and Søegaard, 2018).

The method of renovation and species composition of legume-grass mixtures had no significant effect on the content of neutral and acid fractions of fibre and lignin in dry matter (Table 3). Most often, the fibre content increased in the third year of use of sward. It is known from the literature about the high abundance of legumes (especially lucerne) in fibre fractions (Elgersma and Søegaard, 2016). According to Bélenger and Tremblay (2010), lucerne contains more neutral fibre fraction (NDF), and the organic matter digestibility of this species is lower than that of grasses. In addition to the age of the plants, weather conditions (warmth, good sunshine) also increase the concentration of fibre in the sward. This is confirmed by the Elgersma and Søegaard (2018) study, which showed that in dry years the contents of NDF and ADF in the dry matter of sward increased. Vasiljević et al. (2011) emphasize the importance of the development stage of plants at harvest time in the evaluation of feed quality.

Table 3. Content of neutral and acid detergent fibre (NDF, ADF, ADL) $\left(g \mathrm{~kg}^{-1}\right)$

\begin{tabular}{|c|c|c|c|c|c|c|c|c|c|}
\hline \multirow{3}{*}{ Specification } & \multicolumn{3}{|c|}{ NDF } & \multicolumn{3}{|c|}{ ADF } & \multicolumn{3}{|c|}{ ADL } \\
\hline & \multicolumn{9}{|c|}{ Year of utilization } \\
\hline & $1^{\text {st }}$ & $2^{\text {nd }}$ & $3^{\text {rd }}$ & $1^{\text {st }}$ & $2^{\text {nd }}$ & $3^{\text {rd }}$ & $1^{\text {st }}$ & $2^{\text {nd }}$ & $3^{\text {rd }}$ \\
\hline \multicolumn{10}{|c|}{ Usage of the renovation of the grassland } \\
\hline \multirow{3}{*}{$\begin{array}{c}1 \text { - ploughing } \\
2 \text { - compact harrow } \\
3 \text { - herbicide }+ \text { direct } \\
\text { sowing }\end{array}$} & 572.0 & 630.0 & 590.0 & 325.0 & 387.0 & 362.0 & 33.2 & 51.1 & 65.3 \\
\hline & 535.3 & 639.0 & 626.0 & 304.3 & 379.3 & 378.3 & 34.7 & 54.6 & 66.7 \\
\hline & 564.7 & 622.7 & 634.3 & 319.3 & 318.0 & 366.3 & 35.2 & 58.0 & 69.6 \\
\hline \multicolumn{10}{|c|}{ Mixtures } \\
\hline \multirow{3}{*}{$\begin{array}{c}\text { K - Krasula }+3.5 \mathrm{~kg} \\
\text { white clover } \\
\text { C - Cent } 4 \\
\text { O - Original mixture }\end{array}$} & 576.7 & 636.3 & 662.3 & 324.3 & 376.7 & 404.7 & 35.2 & 52.2 & 79.3 \\
\hline & 560.3 & 629.7 & 566.7 & 311.7 & 387.3 & 339.0 & 31.1 & 55.2 & 57.9 \\
\hline & 535.0 & 625.7 & 621.3 & 312.7 & 383.3 & 363.0 & 36.7 & 56.3 & 64.3 \\
\hline
\end{tabular}

$\mathrm{NDF}$ - neutral fibre fraction, ADF - acid fraction fibre, ADL - lignin's fraction fibre. Usage of the renovation of the grassland: $1^{*}$ - ploughing, 2 - compact disc harrow, 3 - herbicide + direct sowing. Mixtures: - see Figure 3

\section{Nutritive value}

There was no effect of sward renovation method and species composition of mixtures used for resowing on the nutritive quality of feed (Table 4). Lack of significant differences in nutritive value may be associated with the analysis of chemical composition only in the first growth of sward. As Vasiljevic et al. (2011) have shown, the abundance of sward in minerals increases during the growing season, while spring regrowth is characterized by a low concentration of nutrients, energy, and protein. The 3-year average economic and production analysis carried out in this experiment also did not show any influence of the examined factors on the content and net production of energy units and kilograms of total protein produced from one hectare (Gaweł et al., 2018). 
Table 4. Value energy (UFL), protein value of the feed expressed in units of protein digested in the small intestine of dry matter $\left(\mathrm{g} \mathrm{kg}^{-1}\right.$; PDI) and value of the filling units for lactation $(L F U)$

\begin{tabular}{|c|c|c|c|c|c|c|c|c|c|}
\hline \multirow{3}{*}{ Specification } & \multicolumn{3}{|c|}{ UFL } & \multicolumn{3}{|c|}{ PDI $\left(g \cdot \mathrm{kg}^{-1}\right)$} & \multicolumn{3}{|c|}{ LFU } \\
\hline & \multicolumn{9}{|c|}{ Year of utilization } \\
\hline & $\mathbf{1}^{\text {st }}$ & $2^{\text {nd }}$ & $3^{\text {rd }}$ & $1^{\text {st }}$ & $2^{\text {nd }}$ & $3^{\text {rd }}$ & $1^{\text {st }}$ & $2^{\text {nd }}$ & $3^{\text {rd }}$ \\
\hline \multicolumn{10}{|c|}{ Usage of the renovation of the grassland } \\
\hline \multirow{3}{*}{$\begin{array}{c}\text { 1- ploughing } \\
\text { 2- compact harrow } \\
\text { 3- herbicide + direct } \\
\text { sowing } \\
\end{array}$} & 0.95 & 0.92 & 0.67 & 17.9 & 14.10 & 26.7 & 0.84 & 0.72 & 0.84 \\
\hline & 0.94 & 0.93 & 0.67 & 23.5 & 18.12 & 22.9 & 0.80 & 0.71 & 0.83 \\
\hline & 0.94 & 0.93 & 0.66 & 18.1 & 15.27 & 25.8 & 0.80 & 0.71 & 0.83 \\
\hline \multicolumn{10}{|c|}{ Mixtures } \\
\hline \multirow{3}{*}{$\begin{array}{c}\mathrm{K}^{* *} \text { - Krasula }+3.5 \\
\text { kg white clover } \\
\text { C - Cent } 4 \\
\text { O - Original mixture }\end{array}$} & 0.95 & 0.93 & 0.69 & 16.2 & 16.59 & 24.3 & 0.80 & 0.69 & 0.84 \\
\hline & 0.94 & 0.93 & 0.65 & 20.5 & 13.11 & 26.7 & 0.82 & 0.75 & 0.83 \\
\hline & 0.93 & 0.93 & 0.67 & 22.8 & 17.79 & 24.4 & 0.82 & 0.69 & 0.84 \\
\hline
\end{tabular}

UFL - feed unit for lactation, PDI - protein digested in small intestine, LFU - value of the filling units for lactation. Usage of the renovation of the grassland: $1^{*}-$ ploughing, 2 - compact disc harrow, 3 herbicide + direct sowing. Mixtures: $\mathrm{K}^{* *}-$ see Figure 3

The experiment calculated the value of filling units (LFU) to evaluate the ability of animals to consume roughage with the lowest possible consumption of concentrates (Table 4). The influence of the sward renovation method and the species composition of mixtures on this parameter of feed quality were not found. It is believed that the nutritive value is influenced by the proportion of legumes in sward, which age slower than grasses (Peyraud et al., 2009). Rook and Yarrow (2002) obtained a higher filling value in the case of legumes than in the case of grasses, despite the high content of lignin fractions in the dry matter of these plants.

\section{Yield of total protein and relative nutritional value}

The compared methods of grassland renovation and species composition of mixtures had no significant effect on the total protein yield in the first year of use from 370.4 to $578.1 \mathrm{~kg} \mathrm{ha}^{-1}$, and in the third year of use 716.3 to $773.8 \mathrm{~kg} \mathrm{ha}^{-1}$ (Table 5). The observed increase in protein yield in the third year of use resulted from the high percentage of legumes in the sward of mixtures in this period (Figs. 2 and 3). Renovation of permanent grassland carried out in north-eastern Poland by direct resowing and full tillage showed an increase in protein yield by an average of $300 \mathrm{~kg} \mathrm{ha}^{-1}$ in relation to the control (Terlikowski and Barszczewski, 2015). On the other hand, after renovation by direct sowing with a slit seed drill, Mocanu and Hermenean (2009) recorded an increase in protein yield by $105-129 \%$ in relation to the control.

In the three-year period of use, no significant influence of the method of renovation of grassland and species composition of mixtures on relative feed value (Table 5) was found. The best-quality relative nutritional value, of class III, was obtained in the first year of use of the mixtures, due to the achieved compartments value of 103.42-114.93. According to Jeranyama and Garcia (2004), quality grading tables, good beef cattle, older heifers and marginally, dairy cows may be consumers of this feed. In the following years of use, the obtained fodder was classified to the class IV quality, intended for feeding meat cattle or dried dairy cows. 
Table 5. Yield of total protein and relative nutritional value in first cut of the mixtures

\begin{tabular}{|c|c|c|c|c|c|c|}
\hline \multirow{3}{*}{ Specification } & \multicolumn{3}{|c|}{$\begin{array}{l}\text { Yields of total protein } \\
\text { in the first cut }\left(\mathrm{kg} \mathrm{ha}^{-1}\right)\end{array}$} & \multicolumn{3}{|c|}{$\begin{array}{l}\text { Relative nutritional } \\
\text { Value (RFV) }\end{array}$} \\
\hline & \multicolumn{6}{|c|}{ Year of utilization } \\
\hline & $1^{\text {st }}$ & $2^{\text {nd }}$ & $3^{\text {rd }}$ & $1^{\text {st }}$ & $2^{\text {nd }}$ & $3^{\text {rd }}$ \\
\hline \multicolumn{7}{|c|}{ Usage of the renovation of the grassland } \\
\hline 1 - ploughing & 446.11 & 387.79 & 739.33 & 103.42 & 86.79 & 97.06 \\
\hline 2 - compact harrow & 578.12 & 542.71 & 678.11 & 114.93 & 86.47 & 90.51 \\
\hline $\begin{array}{c}3 \text { - herbicide + direct } \\
\text { sowing }\end{array}$ & 370.37 & 456.86 & 773.88 & 106.21 & 88.52 & 88.59 \\
\hline \multicolumn{7}{|c|}{ Mixtures } \\
\hline $\begin{array}{c}\mathrm{K} * * \text { - Krasula }+3.5 \mathrm{~kg} \\
\text { white clover }\end{array}$ & 376.02 & 487.19 & 716.39 & 103.29 & 87.17 & 80.61 \\
\hline C - Cent 4 & 458.87 & 363.79 & 737.38 & 107.33 & 86.80 & 103.28 \\
\hline O - Original mixture & 559.71 & 536.38 & 737.54 & 113.94 & 87.81 & 92.27 \\
\hline
\end{tabular}

RFV- relative nutritional value. Usage of the renovation of the grassland: $1 *$ - ploughing, 2 - compact disc harrow, 3 - herbicide + direct sowing. Mixtures: $\mathrm{K}^{* *}$ - see Figure 3

\section{Conclusions}

1. The compared methods of renovation of grassland sward (full tillage method after ploughing - treatment 1); simplified tillage after surface soil disturbance to the depth of $5 \mathrm{~cm}$ with a compact disc harrow - treatment 2); destruction of degraded sward with herbicide and sowing of mixtures with Moore slit seed drill - treatment 3), gave similar production results, therefore all of them are considered useful in conditions of research for renovation of degraded grassland.

2. In the three-year period of use, characterized by a periodic precipitation deficiency, a tendency to weaker yields for the mixture Cent 4, with short-lived species of grasses, including perennial and Italian ryegrass, was recorded compared to the mixture Krasula and the original mixture.

3. Regardless of the method of renovation and species composition of mixtures used to renovate the sward, legumes withstood moisture deficiency better than grasses, and their percentage in the sward increased in subsequent years of use. Increasing percentage of legumes in the sward positively influenced the content of protein value (PDI), value of the filling units for lactation (LFU) and protein yield $\left(\mathrm{kg} \mathrm{ha}^{-1}\right)$.

4. Good beef cattle, older heifers, and marginally, dairy cows can be fed with fodder obtained in the first year after the renovation of the sward because of range of the relative nutritive value achieved. In the following years, the relative nutritional value worsened, which is why the feed should be used to feed animals with lower nutritional requirements, i.e., meat cattle or dried dairy cows.

5. In the years characterized by rainfall deficiency, renovation of grassland can be carried out by the method of destruction of the sward with a compact disc harrow and sowing of seeds with a grain seed drill. Under these conditions, reseeding should be used, among others, for species that tolerate soil moisture deficiency, such as alfalfa and cocksfoot.

Acknowledgements. The research did not receive any specific grant from funding agencies in the public, commercial, or not-for-profit sectors. 


\section{REFERENCES}

[1] Bélanger, G., Tremblay, G. F. (2010): Fodder quality of legume-based pastures. - NJF Seminar 432. The potential of forage legumes to sustain a high agricultural productivity-A Nordic perspective. NJF Report 6(3): 97-112. Hvanneyri, Iceland.

[2] De Vliegher, A., Van Gils, B., van den Pol-van Dasselaar, A. (2014): Roles and utility of grasslands in Europe. - Grassland Science in Europe 19: 753-755. https://pure.ilvo.be/portal/files/3304733/A_De_Vliegher_3_Multisward_WP1.pdf.

[3] Donnellan, T., Hennessy, T., Keane, M., Thorne, F. (2012): Competitiveness of the dairy sector at farm level un the EU. - Proceedings of the of $24^{\text {th }}$ General Meeting of the European Grassland Federation 3-7 June 2012. Lublin, Poland, Grassland Science in Europe 17: 719-732.

[4] Elgersma, A., Søegaard, K. (2016): Effect of species diversity on seasonal variation in herbage yield and nutritive value of seven binary grass-legume mixtures and pure grass under cutting. - European Journal of Agronomy 78: 73-83.

https://doi.org/10.1016/j.eja.2016.04.011.

[5] Elgersma, A., Søegaard, K. (2018): Changes in nutritive value and herbage yield during extended growth intervals in grass-legume mixtures: effects of species, maturity at harvest, and relationships between productivity and components of feed quality. - Grass and Forage Science 73(1): 78-93. https://doi.org/10.1111/gfs.1228.

[6] Elsaesser, M. (2012): Grassland renovation as a possibility for increasing nitrogen efficiency. - Grassland Science in Europe 17: 607-609.

http://www.europeangrassland.org/fileadmin/media/EGF2012.pdf.

[7] Gaweł, E. (2017): Influence of renovation of grassland on sward yields in the condition of organic farming. - Journal of Research and Applications Agricultural Engineering 62(3): 105-111. http://www.pimr.poznan.pl/biul/2017_3_EG.pdf.

[8] Gawel, E., Madej, A., Grzelak, M. (2018): The effect of renovation of the permanent grassland on some economic evaluation parameters in conventional condition. - Roczniki Naukowe Stowarzyszenia Ekonomistów Rolnictwa i Agrobiznesu XX (6): 61-69. (in Polish). doi:10.5604/01.3001.0012.7733.

[9] Głąb, T., Żabiński, A., Sadowska, U. (2016): Tractor traffic and nitrogen fertilization affect the herbage production of the red clover/grass sward. - Zemdirbyste-Agriculture 103(4): 347-354. Doi. 10.13080/z-a.2016.103.044.

[10] Golka, W., Żurek, G., Kamiński, J. R. (2016): Permanent grassland restoration techniques - an overview. - Agricultural Engineering 20(4): 51-58. https://doi.org/10.1515/agriceng-2016-0063.

[11] Grabarczyk, S. (1989): Potrzeby wodne użytków zielonych i traw. - Zeszyty Problemowe Postępów Nauk Rolniczych i Leśnych 343: 43-56.

[12] Grace, C., Boland, T. M., Sheridan, H., Lott, S., Brennan, E., Fritch, R., Lynch, M. B. (2018): The effect of increasing pasture species on herbage production, chemical composition and utilization under intensive sheep grazing. - Grass and Forage Science 73: 852-864. https://doi.org/10.1111/gfs.12379.

[13] GUS. (2018): Production of agricultural and horticultural crops in 2017. - Warszawa. https://produkcja_upraw_rolnych_i_ogrodniczych_w_2017\%20(14).pdf.

[14] Isselstein, J., Kayser, M. (2015): Grassland renovation and consequences for nutrient management. - Proceedings of $23^{\text {rd }}$ International Grassland Congress 2015 - Keynote Lectures. New Delhi, India, Grassland production and utilization: 105-116. https://www.internationalgrasslands.org/files/igc/publications/2015/Isselstein,\%20Johann es.pdf.

[15] Jeranyama, P., Garcia, A. D. (2004): Understanding relative feed value (RFV) and relative forage quality (RFQ). - Extension Extra. Paper 352.

http://openprairie.sdstate.sdu/extension_extra. 
[16] Kayser, M., Müller, J., Isselstein, J. (2018): Grassland renovation has important consequences for $\mathrm{C}$ and $\mathrm{N}$ cycling and losses. - Food and Energy Security 7: e00146. https://onlinelibrary.wiley.com/doi/10.1002/fes3.146.

[17] Klimek, S., Kemmermann, A. R., Hofmann, M., Isselstein, J. (2007): Plant species richness and composition in management and environmental factor. - Biological Conservation 134: 559-570. http://doi:10.1016/j.biocon.2006.09.007.

[18] Kulik, M. A. (2010): The effect of regeneration technology of meadow sward on its species composition. - Annales Universitatis Mariae Curie-Skłodowska Lublin- Polonia Sectio EE 65(4): 95-104. (in Polish).

http://wydawnictwo-old.up.lublin.pl/annales/Agricultura/2010/4/11.pdf.

[19] Lesschen, J. P., Elbersen, B., Hazeu, G., van Doorn, A., Mucher, S., Velthof, G. (2014): Defining and classifying grasslands in Europe. - Final report, Alterra, part of Wageningen UR, Wageningen.

https://ec.europa.eu/eurostat/documents/2393397/8259002/Grassland_2014_Task+1.pdf/ 8b27c17b-b250-4692-9a58-f38a2ed59edb.

[20] Linn, J. G., Martin, N. P. (1989): Forage quality test and interpretation. St Paul. University of Minnesota, Extension Service Publ. AG-FO 2637: 1-5.

[21] Łyszczarz, R., Dembek, R., Suś, R., Zimmer-Grajewska, M., Kornacki, P. (2010): The overdrilling of degraded grass communities as an environmentally-friendly method of their regeneration. - Woda-Środowisko-Obszary Wiejskie 10 z. 4(32): 129-148. (in Polish). http://www.itep.edu.pl/wydawnictwo/woda/zeszyt_32_2010/artykuly/Lyszczarz\%20i\%20 in.pdf.

[22] MacDonald, J. D., Chantigny, M. H., Angers, D. A., Rochette, P., Royer, I., Gasser, M. O. (2011): Soil soluble carbon dynamics of manured and unmanured grassland following chemical kill and ploughing. - Geoderma 164(1-2): 64-72. doi.org/10.1016/j.geoderma.2011.05.011.

[23] MacDonald, J. D., Rochette, P., Chantigny, M. H., Angers, D. A, Royer, I., Gasser, M. O. (2011): Ploughing a poorly drained grassland reduced $\mathrm{N}_{2} \mathrm{O}$ emissions compared to chemical fallow. - Soil Tillage Research 111: 123-132. doi:10.1016/j.still.2010.09.005.

[24] Mantino, A., Ragaglini, G., Nassi o di Nasso, N., Tozzini, C., Taccini, F., Bonari, E. (2016): Alfa (Medicago sativa L.) overseeding on mature switchgrass (Panicum virgatum L.) stand: biomass yield and nutritive value after the establishment year. - Italian Journal of Agronomy 11: 747. doi:10.4081/ija.2016.747.

[25] Mocanu, V., Hermenean, I. (2009): Restoration of grassland multifunctionality by direct drilling method - a solution for sustainable farming system. - Research-Development Institute for Grassland. ICDP Braşov, Romania 26: 71-74. http://www.incdafundulea.ro/rar/nr26/rar26.14.pdf.

[26] Peyraud, J. L., Le Gall, A., Lüscher, A. (2009): Potential food production from forage legume-based-systems in Europe: an overview. - Irish Journal of Agricultural and Food Research 48: 115-135. https://doi.org/10.1111/gfs.12124.

[27] Reheul, D., Cougnon, M., Kayser, M., Pannecouque, J., Swanckaert, J., De Cauwer, B., van den Pol-van Dasselaar, A., De Vliegher, A. (2017): Sustainable intensification in the production of grass and forage crops in the Low Countries of north-west Europe. - Grass and Forage Science 72: 369-381. doi.org/10.1111/gfs.12285.

[28] Reinsch, T., Loges, R., Kluß, C., Taube, F. (2018): Renovation and conversion of permanent grass-clover swards to pasture or crops: Effects on annual $\mathrm{N}_{2} \mathrm{O}$ emissions in the year after ploughing. $\quad-$ Soil and Tillage Research 175: 119-129. https://doi.org/10.1016/j.still.2017.08.009.

[29] Rook, A. J., Yarrow, N. H. (2002): Incorporating grazing behaviour measurements in models to predict herbage intake by grazing dairy cows. - Grass and Forage Science 57: 19-24. https://doi.org/10.1046/j.1365-2494.2002.00297.x. 
[30] Terlikowski, J., Barszczewski, J. (2015): The effectiveness of permanent grassland renovation under different soil and climatic conditions. - Journal of Research and Applications Agricultural Engineering 60(4): 112-119.

http://www.pimr.poznan.pl/biul/2015_4_TB.pdf.

[31] Tremblay, G. E., Bélanger, G., Simili da Silva, M., Lajeunesse, J., Papadopoulos, Y. A., Filmore, S. A. E., Jobim, C. C. (2015): Herbage energy to protein ratio of binary and complex legume-grass mixtures. Grassland and forages in high output dairy farming systems. - Proceedings of the $18^{\text {th }}$ Symposium of the European Grassland Wageningen. The Netherlands, Grassland Science in Europe 20: 328-330. http://www.europeangrassland.org/fileadmin/media/EGF2015.pdf.

[32] Vasiljević, S., Ćupina, B., Krstic, Đ., Pataki, I., Katanski, S., Milošević, B. (2011): Seasonal changes of proteins, structural carbohydrates, fats and minerals in herbage dry matter of red clover (Trifolium pretense L.). - Biotechnology in Animal Husbandry 27(4): 1543-1550. DOI: 10.2298/BAH1104543V.

[33] Velthof, G. L., Hoving, I. E., Dolfing, J., Smit, A., Kuikman, P. J., Oenema, O. (2010): Methode and timing of grassland renovation affects herbage yield, nitrate leaching, and nitrous oxide emission in intensively managed grasslands. - Nutrient Cycling in Agroecosystems 86: 401-412. https://doi.org/10.1007/s10705-009-9302-7.

[34] Zając, M., Spychalski, W., Goliński, P. (2010): Effect of different methods of sward renovation on selected physical and chemical soil properties. - Grassland Science in Europe 15: 226-228.

http://www.europeangrassland.org/fileadmin/media/EGF2010_GSE_vol15.pdf. 